\title{
16. Türkçe öğretmeni adaylarının internet tabanlı okuma motivasyonu ve etkileşim ile mobil öğrenme tutumları arasındaki ilişkinin incelenmesi
}

Abdurrahman GÜZEL ${ }^{1}$

Yusuf Mete ELKIRAN²

APA: Güzel, A.; Elkıran, Y. M. (2021). Türkçe öğretmeni adaylarının internet tabanlı okuma motivasyonu ve etkileşim ile mobil öğrenme tutumları arasındaki ilişkinin incelenmesi. RumeliDE Dil ve Edebiyat Araşttrmaları Dergisi, (24), 324-341. DOI: 10.2900o/rumelide.996583.

$\ddot{O} \mathbf{z}$

$\mathrm{Bu}$ araştırmanın amacı Türkçe öğretmeni adaylarının internet tabanlı okuma motivasyonu ve etkileşimleri ile mobil öğrenme tutumları arasındaki ilişkiyi belirlemektir. Bu kapsamda Türkiye'nin batısındaki bir devlet üniversitesinin Türkçe öğretmenliği programında öğrenim gören farklı sınıf düzeyinden 197 öğretmen adayının görüşüne başvurulmuştur. Nicel araştırma yöntemlerinden ilişkisel tarama yönteminden yararlanılmıştır. Araştırmada veri toplama aracı olarak "İnternet Tabanlı Okuma Motivasyonu ve Etkileşim Ölçeği” ve “Mobil Öğrenme Tutum Ölçeği” kullanılmıştır. Elde edilen bulguların analizi sonucunda verilerin normal dağılım gösterdiği saptandığından araştırmada bağımsız örneklem t testi ve tek yönlü Anova analizleri ile aritmetik ortalama ve standart sapma değerleri kullanılmıştır. Analizler doğrultusunda katılımcıların internet tabanlı okuma motivasyonu ve etkileşimlerinin orta düzeyde olduğu sonucuna ulaşılmıştır. Bununla beraber katılımcıların mobil öğrenme tutumlarının yüksek düzeyde olduğu sonucuna ulaşılmıştır. İnternet tabanlı okuma motivasyonu ve etkileşim ölçeğinin bütünü ve alt boyutları göz önüne alındığında cinsiyet, sınıf düzeyi ve bir günde ortalama internette geçirilen süre değişkenlerine göre anlaml farklılığa ulaşılamamıştır. İnternet tabanlı okuma motivasyonu ve etkileşimlerinin ölçeğin bütünü, yeterlik, zorluk ve adanmışlık alt boyutlarında akademik başarı düzeyi değişkenine göre anlamlı farklılığa ulaşılamamıştır. Ayrıca yine internet tabanlı okuma motivasyonu ve etkileşimlerinin ölçeğin bütünü, zorluk, adanmışlık ve kaçınma alt boyutlarında yıllık ortalama kitap okuma sayısı değişkenine göre anlamlı farklılığa ulaşılamamıştır. Mobil öğrenme tutumları içinde ölçeğin bütünü dikkate alındığında cinsiyet, sınıf düzeyi, akademik başarı, yıllık ortalama kitap okuma ve günde ortalama internette geçirilen süre değişkenlerine göre anlamlı farklılık görülmemiştir. Araştırma bulgularına göre Türkçe eğitimi öğretmen adaylarının internet tabanlı okuma motivasyonu ve etkileşimleri ile mobil öğrenme tutumları arasında zayıf düzeyde, pozitif ve anlamlı bir ilişki olduğu sonucuna ulaşılmıştır.

Anahtar kelimeler: İnternet tabanlı okuma, mobil öğrenme, okuma motivasyonu, Türkçe öğretmen adayı

Prof. Dr., Başkent Üniversitesi, Eğitim Fakültesi, Türkçe Öğretmenliği Bölümü (Ankara, Türkiye), guzel@baskent.edu.tr, ORCID ID: 0000-0003-2896-1156 [Araştırma makalesi, Makale kayıt tarihi: 10.06.2021-kabul tarihi: 19.09.2021; DOI: 10.29000/rumelide.996583]

Öğr. Gör. Dr., Çanakkale Onsekiz Mart Üniversitesi, Eğitim Fakültesi, Bilgisayar ve Öğretim Teknolojileri Eğitimi, (Çanakkale, Türkiye), ymelkiran@gmail.com, ORCID ID: 0000-0001-8372-8555

Adres $\mid$ Address

RumeliDE Dil ve Edebiyat Araştırmaları Dergisi Osmanağa Mahallesi, Mürver Çiçeği Sokak, No:14/8 Kadıköy - ISTANBUL / TÜRKIYE 34714 e-posta: editor@rumelide.com

RumeliDE Journal of Language and Literature Studies Osmanağa Mahallesi, Mürver Çiçeği Sokak, No:14/8

Kadıköy - ISTANBUL / TURKEY 34714 tel: +90 $5057958124,+902167730616$

e-mail: editor@rumelide.com

phone: +90 505 7958124, +90 2167730616 


\title{
Examining the relationship between prospective Turkish teachers internet based reading motivation and engagement and mobile learning attitude
}

\begin{abstract}
The aim of this study is to examine the relationship between prospective Turkish teachers' internet based reading motivation and engagement and mobile learning attitude. In this context, the opinions of 197 pre-service teachers from different grade levels of Pre-Service Turkish Language Teachers of a state university in the west of Turkey were consulted. Relational screening method, which is one of the quantitative research methods, was used. "Internet Based Reading Motivation and Engagement Scale" and "Mobile Learning Attitude Scale" were used as data collection tools in the research. Based on the analysis, it was concluded that the internet-based reading motivation and engagement of the participants were at a medium-level. In addition, it was concluded that the mobile learning attitudes of the participants were at a high level. Considering the whole and sub-dimensions of the internetbased reading motivation and engagement scale, no significant difference could be reached according to the variables of gender, grade level and the average time spent on the internet in a day. No significant difference was reached in the sub-dimensions of internet-based reading motivation and interactions as a whole, competence, difficulty and dedication, according to the variable of academic standing. Considering the whole scale among mobile learning attitudes, there was no significant difference in terms of gender, grade level, academic achievement, annual average book reading and average time spent on the internet in a day. According to research findings, there is a weak, positive and significant relationship between prospective Turkish teachers' internet based reading motivation and engagement and mobile learning attitude.
\end{abstract}

Keywords: internet-based reading, mobile learning, prospective Turkish teacher reading motivation

\section{Giriş}

İnsanoğlu iletişim ihtiyacını karşılamak için devamlı teknolojik gelişmeleri takip edip yaşamında yeni araç ve gelişmelere uyum sağlamaya çalışmaktadır. Teknolojideki hızlı gelişmeler, insanlar arasındaki iletişimin şekil ve biçimlerinde sürekli değişmelere neden olmaktadır. 20.yüzyılın son çeyreğinde yonga teknolojilerindeki gelişmelerle başlayan bilgisayar ve teknolojilerinin dönüşümü hayatın her alanını olumlu veya olumsuz başkalaşımlara sürüklemiştir. Zamanla sadece bilgisayarların iletişiminde kullanılan internet teknolojisi, cep telefonları ve dokunmatik akıllı telefonların icadıyla mobil araçlara yansımış ve milyarlarca kullanıcının anlık iletişim kurduğu bir yaygınlığa yönelmiştir. Son yıllarda internette üretilen veriler, her geçen yll bir öncekine göre misli oranda arttı̆̆ yüksek bir veri üretimi ivmesine ulaşmıştır. Her alanda olduğu gibi eğitim ve öğretim konularında da önemli gelişmeler olmuştur.

Yazılı medya zamanla kağıt ve matbaadan dijitale doğru evrilmeye başlamıştır. Bu değişimlerin eğitim öğretim süreçlerinin üzerinde etkisi büyüktür. Dijital araçların eğitimde kullanımı günden güne yaygınlaşmış ve ayrıca uzaktan öğretimde de devrim niteliğinde gelişmeler olmuştur. Geçmişte mektup ile haberleşme var iken uzaktan öğretim de bire bir olarak eğitim mektupla yapılırken günümüzde bireysel değil gruplar halinde uzaktan eğitimler yapılabilmektedir. Günümüzde mektubun yerini epostalar alsa da doğrudan görüntülü iletişim imkanları var olduğu için yazışarak uzaktan öğretim sadece imkan kısıtlamalarının olduğu zamanlarda zorunlu olarak tercih edilir olmuştur. İçinde bulunduğumuz

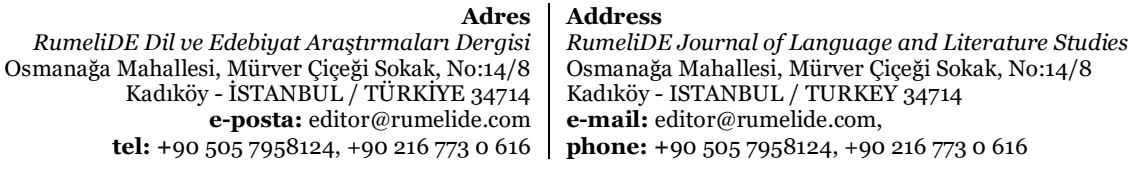


2020-2021 öğretim yıllarında ise iletişim teknolojilerinin marifetiyle küresel bir virüs salgınından kaynaklı olarak zorunlu ve ani uzaktan eğitim, eğitim-öğretim faaliyetlerinin her aşama ve kademesinde mecburen tam veya yarı zamanlı olarak uygulanmıştır. Bu dönemde kullanılan acil uzaktan eğitim her ne kadar verim yönünden tartışmalara neden olsa da eğitim ve öğretim faaliyetlerinin tamamen durmasının önüne geçmiştir.

Hayatın her alanına dijitalin yayılımı söz konusu olmuştur. Birçok vatandaşlık iş ve işlemleri böylelikle mobil sistemler üzerinden takip edilebilir ve taleplere göre ihtiyaçlar karşılanabilir hale gelmiştir. Taşınabilir mobil teknolojileri ile e-posta, e-okul, e-ders ve e-devlet gibi sistemler yaygın bir şekilde kullanılmaya başlamıştır. Çünkü bu otomasyonlar hem daha kullanışlı hem de daha ekonomik bir imkan sunmaktadır. İnternetin zamandan ve mekandan bağımsız erişim kolaylığı sunması mobil teknolojileri avantajları hayatın bir çok kolunda kullanılır hale gelmiştir. Kullanıcılarına firsat eşitliği yönünden rahat erişim imkanı vererek her hangi bir mekana mecburi olarak sınırlı kalmadan dijital teknolojilerin kullanımı ile mobil öğrenmeler söz konusu olmuştur (Abdullah ve Ward; 2016; Fabergerd, Rekkedal ve Russell, 2003; Kukulska-Hulme ve Traxler, 2005). Mobil öğrenme eş zamanlı veya eş zamansız içinde bulunulan mekan ve şartlara göre uyarlanabilen öğrenmelerdir (Bulun, Gülnar ve Güran, 2004). Hayat boyu öğrenme, bir programa bağlı veya bağımsız olarak öğrenme konuları da mobil öğrenme konuları içinde değerlendirilmektedir. İnternetle 21. yüzyılın başlarında özdeşleşen sabit olarak kullanılmak zorunda olan kişisel bilgisayarların kullanım zorunluluğunun ortadan kalktı̆̆ bir öğrenmedir. Bu öğrenme çoklu ortam araç ve tasarımları ile desteklenmektedir. Basit bir mp3 oynatıcı bir cihaz veya evlerde sabit televizyonlar bile bu öğrenme imkanını sunabilir. Bu bağlamda öğrenme materyalinin hazırlandığı araca bağlı kalındığı söz konusudur. İletişim kuramında mesajın kaynaktan çıkarak hedefe ulaştırılmasında kullanılan kanal mobil cihazlardır. Bu mobil cihazların kullanım kolaylığı ve öğrenenin ona olan aşinalığı öğrenmeyi olumlu veya olumsuz olarak etkileyebilir.

Okuma becerisi örgün öğretim ile eğitim öğretim organlarında bireyin edindiği bir beceridir (Özden, 2019; Kurudayığlu ve Çetin, 2015). Okuma becerisi bilgiye erişim ve bilginin geçerliliği ile güvenirliğini sorgulama imkanı sağlar (Geçgel, Kana, Öztürk ve Akkaş; 2020). Okuma arzusunun gelişmesi, okumayı sürdürme ve okumaya yönelme için dijital araçlara olan yatkınlı ve kullanıcı dostu araçların kolaylık sağlaması ile mümkündür. Bu dijital araçlar ve hayatımıza kattığı yeni kavramlar hem yaşantımızda hem de eğitim öğretim süreçlerinde okuma motivasyonunu etkilemektedir. Okuma motivasyonu, okuma etkinliklerinin süreçlerini ve katılımı etkileyen bireysel gayeler, değerler ve inançlar olarak değerlendirilmektedir (Wigfield ve Guthrie, 1997). Okuma motivasyonu yüksek olan bireyler hem okumaya daha adanmış hem de okuma stratejilerini daha yaygın olarak kullanan kişisel amaçlarına ve gayelerine ulaşmak için okuyan bireylerdir (Guthrie, Anderson, Alao ve Rinehart, 1999). Geleneksel olarak anlama (dinleme, izleme ve okuma) ve anlatma (konuşma, yazma) becerilerinin gelişimi dil ve kültür zenginlikleri üzerinden gerçekleşmektedir. Bununla beraber okuma yazma eylemi de metin, okur ve yazar üçlüsünü bir arada düşündürmektedir. Geçmişte metin, doğrudan papirüsler üzerine simgelerin, harflerin ve şekillerin belirli bir sistematiğe göre çizilmesinden meydana gelirken günümüzde dijital araçlar vasıtasıyla ses ve görüntü ile zenginleştirilmiş olabilmekte ve tablet, akıllı telefon, akıllı tahta ve monitör gibi araçların ekranlarından okunup izlenerek anlamlandırılmaya başlanmıştır (Churchill, 2016; Erbaş ve Demirer, 2015; Larson, 2012). Medya ve eğitim öğretim ekranlar üzerinden takip edilmeye başlanmıştır. Böylelikle tüm dil becerilerinde olduğu gibi dijital araçların yaygınlaşmasından kaynaklı olarak okuma becerisinin gelişimi ile ilgili ekran okuma, dijital okuma, mobil okuma ve ekran okuryazarlığ gibi yeni kavramlar ortaya çıkmıştır (Akkaya ve Toprak, 2020; Duran ve Özkul, 2015; Gilster, 1997; Göçer ve Tabak, 2013; Güneş, 2016; Kana,2015; Macit ve Demir, 2016; Maden, 2012; Özbay ve Özdemir, 2014).

\section{Adres | Address}

RumeliDE Dil ve Edebiyat Araştırmalar Dergisi $\quad$ RumeliDE Journal of Language and Literature Studies Osmanağa Mahallesi, Mürver Çiçeği Sokak, No:14/8 Osmanağa Mahallesi, Mürver Çiçeği Sokak, No:14/8 Kadıköy - İSTANBUL / TÜRKIYE 34714 Kadıköy - ISTANBUL / TURKEY 34714 e-posta: editor@rumelide.com e-mail: editor@rumelide.com, tel: +90 505 7958124, +90 2167730616 phone: +90 505 7958124, +90 2167730616 
Dijital araçlardan okuma ile ilişkili olarak çok yönlü çalışmalar yapılmıştır. "E-kitap okumaya yönelik tutum ölçeği”, "Ekran okumaya yönelik tutum ölçeği”, “Ekran okuma öz yeterlik algı ölçeği”, "Dijital okuma eğilimi ölçeği”, "Dijital okuryazarlık ölçeği”, "Öğretmen adayları için dijital okumaya yönelik tutum ölçeği”, gibi alan yazında bu yeni kavramlarla ilişkili olarak araştırmalarda kullanılan birçok ölçme aracı mevcuttur (Bulut ve Karasakaloğlu, 2018; Güneş ve Susar, 2014; Sulak, 2019; Susar, 2017; Ulu, 2018; Yurdakal ve Susar, 2021). "internet tabanlı okuma motivasyonu ve etkileşim" ölçme aracı ile internet kaynakları odaklanarak diğer çalışmalardan ayrı okuma motivasyonu ve eğitim konusu üzerinde çalışılmıştır (Ata ve Alparslan, 2019). Bu bağlamda internet tabanlı okuma motivasyonu kavramı da 21. yüzyılın hayatımızda vazgeçilmez kıldığı internet teknolojileri ve ekranlarının bir getirisidir. Üst seviye okuma yeteneğine sahip olmak öğrenci, öğretmen ve bireyler için beklenen bir beceri haline gelmeye başlamıştır. Özellikle dil becerilerinin öğretiminde doğrudan öğretmenin özellikleri ve becerileri aranan zorunlu ihtiyaç haline gelmektedir. Türkçe öğretmen adaylarından da öğrencilerine okuma motivasyonları sağlamaları beklenmektedir.

Yapılan açıklamalar doğrultusunda bu çalışmada Türkçe öğretmen adaylarının internet tabanlı okuma motivasyonu ve etkileşimleri ile mobil öğrenme tutumları arasındaki ilişkinin ortaya konulması amaçlanmıştır. Böylelikle öğretmen adaylarının dijital ortamda okuma ve etkileşim algıları ile mobil öğrenme tutumları hakkında fikir edinilmesi düşünülmektedir. Araştırma amacına uygun olarak belirlenen araştırma problemleri aşağıda sunulmuştur:

1. Türkçe öğretmeni adaylarının internet tabanlı okuma motivasyonu ve etkileşimleri ne düzeydedir?

2. Türkçe öğretmeni adaylarının mobil öğrenme tutumları ne düzeydedir?

3. Türkçe öğretmeni adaylarının internet tabanlı okuma motivasyonu ve etkileşimleri cinsiyet, sınıf, akademik başarı, ortalama bir günde internette geçirdikleri süre ve yıllık ortalama okudukları kitap sayısı değişkenlerine göre anlamlı bir farklılık göstermekte midir?

4. Türkçe öğretmeni adaylarının mobil öğrenme tutumları cinsiyet, sınıf, akademik başarı, ortalama bir günde internette geçirdikleri süre ve yıllı ortalama okudukları kitap sayısı değişkenlerine göre anlamlı bir farklılık göstermekte midir?

5. Türkçe öğretmeni adaylarının internet tabanlı okuma motivasyonu ve etkileşimleri ile mobil öğrenme tutumları arasında bir ilişki var mı?

\section{Yöntem}

\section{Araştırmanın modeli}

Bu ilişkisel tarama modelinde tasarlanan bu araştırmada, Türkçe öğretmeni adaylarının internet tabanlı okuma motivasyonu ve etkileşimleri ile mobil öğrenme tutumları arasındaki ilişkiyi incelemek amacıyla nicel araştırma yöntemi kullanılmıştır. Tarama araştırmalarında veriler bir topluluk veya grubun önceden seçilmiş özellikleri belirlemek amacıyla toplanır (Büyüköztürk, Kılıç Çakmak, Akgün, Karadeniz ve Demirel, 2018). İlişkisel tarama modellerinde ise birden fazla değişkenin birlikte değişim durumları veya seviyeleri algılanmak istenir (Karasar, 2007). Bu araştırmada Türkçe öğretmeni adaylarının internet tabanlı okuma motivasyonu ve etkileşimleri ile mobil öğrenme tutumları, kişisel bilgi formu ve ölçeklerdeki değişkenler ve maddeler arası ilişkiler incelenmiştir.

\section{Veri toplama araçları}

Verileri toplamak amacıyla kişisel bilgi formu, mobil öğrenme tutum ve internet tabanlı okuma motivasyonu ve katılım ölçme araçları kullanılmıştır. Araştırmacılar tarafından hazırlanan kişisel bilgi

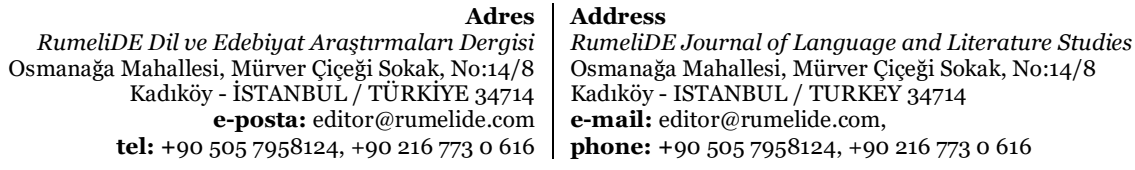


formunda, öğretmen adaylarının cinsiyetine, sınıf düzeyine, not ortalamasına, yılda okudukları kitap sayısına ve internette geçirdikleri günlük süreye yönelik sorular yer almaktadır.

Knezek ve Khaddage (2013) tarafından geliştirilen beşli likert tipi ölçek olan "Mobil Öğrenme Tutum Ölçeğı”; Çam, Uysal, Kıyıcı ve İşbulan (2019) tarafından Türk kültürüne uyarlanmış hali kullanılmıştır. Uyarlanan ölçek bir ile beş arasında likert türünde puanlamayı gerektirmektedir. Ölçek bütün olarak tek boyuttan oluşmaktadır. Ölçme aracında ters madde bulunmamaktadır. Ölçeğin madde sayısı yedidir. Ölçekten en düşük yedi puan, en yüksek 35 puan alınabilir. Elde edilen puanlar 1-1.80 arası kesinlikle katılmıyorum, 1.81-2.60 arası katılmıyorum, 2.61-3.40 arası kararsızım veya orta derecede katılıyorum, 3.41-4.20 arasında katılıyorum ve 4.21-5.00 arasında kesinlikle katılıyorum düzeyinde değerlendirilmektedir.

Braten, Brandmo ve Kammerer (2019) tarafindan geliştirilen 10'lu likert tipi ölçek olan "İnternet Tabanlı Okuma Motivasyonu ve Katılım Ölçeği”nin Ata ve Alparslan (2019) tarafından Türkçeye uyarlanmış hali kullanılmıştır. Uyarlanan ölçek bir ile on arasında likert türünde puanlamayı gerektirmektedir. Ölçek yeterlik, zorluk, adanmışlık ve kaçınma olmak üzere dört boyuttan oluşmaktadır. Ölçme aracında ters puanlanan madde bulunmamaktadır. Ölçeğin madde sayısı 12'dir. Ölçekten en düşük 12 puan, en yüksek 120 puan alınabilir. Elde edilen puanlar düşük, orta ve yüksek olarak gruplandırılırsa; 10'luk skalada, 1.00-4.00 arası düşük, 4.01-7.00 arası orta düzey ve 7.01-10.00 arası yüksek düzey olarak değerlendirilmektedir.

Araştırma kapsamında güvenirlik çalışması yapılmıştır. “Mobil Öğrenme Tutum Ölçeği” için hesaplanan Cronbach-Alfa iç tutarlılık katsayısı .864 ve "İnternet Tabanlı Okuma Motivasyonu ve Katılım Ölçeği” bütünü için Cronbach-Alfa iç tutarlılık katsayısı .802 olarak hesaplanmıştır. “'İnternet Tabanlı Okuma Motivasyonu ve Katılım Ölçeği”” alt boyutları için Cronbach-Alfa iç tutarlılık katsayısı Yeterlik alt boyutunda .830 , Zorluk alt boyutunda .868 , Adanmışlık alt boyutunda .849 , Kaçınma alt boyutunda .879 olarak hesaplanmıştır. Buna göre ölçeklerin güvenilir olduğu sonucuna varılabilir.

\section{Verilerin analizi}

Araştırmada nicel veri analiz programlarından SPSS paket programı kullanılmıştır. Araştırmada standart sapma (Ss) ve aritmetik ortalama $(\bar{x})$ değerleri kullanılmıştır. George ve Mallery'e göre (2010) normalliği sağlayan değer aralıkları (+2.0) - (-2.0) arasındadır. Bu araştırmadan elde edilen çarpıklık ve basıklık değerleri -2 ile +2 arasında değer almıştır. çarpıklık ve basıklık değerleri normal dağılım gösterdiği için araştırmada analizler için t testi, tek yönlü ANOVA ve pearson korelasyon analizleri uygulanmıştır.

\section{Araştırmanın örneklem grubu}

Araştırmanın örneklem grubunu, Çanakkale Onsekiz Mart Üniversitesi Türkçe Eğitimi Ana Bilim Dalında öğrenim gören 197 Türkçe öğretmeni adayı oluşturmaktadır. Araştırmanın örneklem grubuna dair tanımlayıcı istatistik analizleri verilmiştir.

Tablo 1. Araştırmaya katılanların cinsiyetleri

\begin{tabular}{lll}
\hline Cinsiyet & f & \% \\
\hline Kadın & 149 & 75.6 \\
Erkek & 48 & 24.4 \\
\hline
\end{tabular}

RumeliDE Dil ve Edebiyat Araştırmaları Dergisi Osmanağa Mahallesi, Mürver Çiçeği Sokak, No:14/8 Kadıköy - İSTANBUL / TÜRKIYE 34714 e-posta: editor@rumelide.com tel: +90 505 7958124, +90 2167730616
Address

RumeliDE Journal of Language and Literature Studies

Osmanağa Mahallesi, Mürver Çiçeği Sokak, No:14/8

Kadıköy - ISTANBUL / TURKEY 34714

e-mail: editor@rumelide.com,

phone: +90 505 7958124, +90 2167730616 
Tablo 1 incelendiğinde araştırmanın katılımcılarının \%75.6'sının kadın, \% 24.4'ünün erkek olduğu görülmektedir.

Tablo 2. Araştırmaya katılanların sınıf düzeyleri

\begin{tabular}{lll}
\hline Sinif & f & \% \\
\hline 1. Sinif & 28 & 14.2 \\
2. Sinif & 30 & 15.2 \\
3. Sinif & 79 & 40.1 \\
4. Sinif & 60 & 30.5 \\
\hline
\end{tabular}

Tablo 2 incelendiğinde araştırmaya katılanların \%14.2'sinin birinci sınıf, \%15.2'sinin ikinci sınıf, \%40.1’inin üçüncü sınıf, \%30.5’inin ise dördüncü sınıf olduğu görülmektedir.

Tablo 3. Araştırmaya katılanların akademik başarı ortalamaları

\begin{tabular}{lll}
\hline Not Ortalamaları & f & \% \\
\hline 0-2,5 Puan & 13 & 6.6 \\
$2,51-3$, oo Puan & 68 & 34.5 \\
$3,01-4$, oo Puan & 116 & 58.9 \\
\hline
\end{tabular}

Tablo 3 incelendiğinde araştırmaya katılanların \%6.6'sının 0-2.5 puan, \%34.5’inin 2.51-3.0o puan arası ve \%58.9'unun 3.01-4.o puan arası not ortalamasına sahip olduğu görülmektedir.

Tablo 4. Araştırmaya katılanların yıllık ortalama okudukları kitap sayısı

\begin{tabular}{lll}
\hline Kitap Sayısı & f & \% \\
\hline o-5 Kitap & 39 & 19.8 \\
6-10 Kitap & 63 & 32 \\
11-15 Kitap & 41 & 20.8 \\
16 ve Üzeri Kitap & 54 & 27.4 \\
\hline
\end{tabular}

Tablo 4 incelendiğinde araştırmaya katılanların bir yılda ortalama \%19.8’inin 0-5 kitap, \%32'sinin 6-10 kitap, \%20.8'inin 11-15 kitap, \%27.4'ünün ise 16'dan fazla kitap okuduğu görülmektedir.

Tablo 5. Araştırmaya katılanların günlük ortalama internette geçirdikleri süre

\begin{tabular}{lll}
\hline Süre & f & $\%$ \\
\hline 0-1 Saat & 10 & 5.1 \\
2-3 Saat & 36 & 18.3 \\
4-6 Saat & 80 & 40.6 \\
7 ve Üzeri Saat & 71 & 36 \\
\hline
\end{tabular}

Tablo 5 incelendiğinde araştırmaya katılanların bir günde ortalama \%5.1'inin 0-1 saat, \%18.3’ünün 2-3 saat, \%40.6’sının 4-6 saat, \%36'sının ise yediden fazla saat internette zaman geçirdikleri görülmektedir.

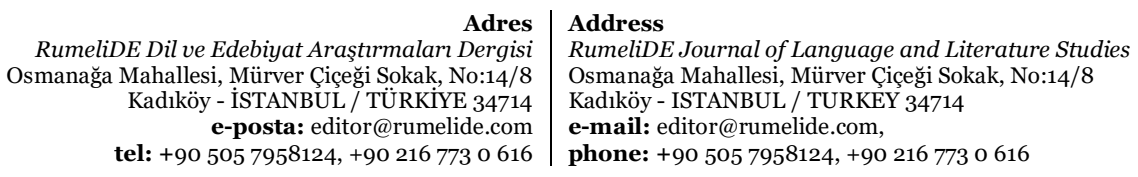




\section{Etik kurulu izni}

Araştırmada uygulanan ölçekler kullanılmadan önce ölçekleri uyarlayan araştırmacılardan e-posta yoluyla kullanım izni alınmıştır. Araştırma bir Eğitim Fakültesi’nde öğrenim gören öğretmen adaylarıyla gerçekleştiği için bu Eğitim Fakültesi’nden ölçeklerin uygulanmasıyla ilgili resmi olarak yazı ile izin alınmıştır. Çanakkale Onsekiz Mart Üniversitesi Sosyal Bilimler ve Eğitim Bilimleri Etik Kurulu 08.12.2020 tarih, 06/44 sayılı kararı ile araştırmanın bilimsel etik kurallara uygun olduğu kararı verilmiştir.

\section{Bulgular}

Tablo 6. Türkçe öğretmeni adaylarının dijital yazma tutumları ve dijital okuma eğilimlerine ilişkin analiz sonuçları

\begin{tabular}{llll}
\hline & $\mathbf{N}$ & $\overline{\mathbf{x}}$ & $\mathbf{S}$ \\
\hline Mobil Öğrenme Tutumları & 197 & 3.69 & .78 \\
$\begin{array}{l}\text { İnternet Tabanlı Okuma Motivasyonu } \\
\text { ve Katılımları }\end{array}$ & 197 & 5.67 & 1.29 \\
Yeterlik Boyutu & & & \\
Zorluk Boyutu & 197 & 7.4 & 1.81 \\
Adanmışlık Boyutu & 197 & 4.93 & 2.12 \\
Kaçınma Boyutu & 197 & 6.17 & 1.92 \\
\hline
\end{tabular}

Tablo 6 incelendiğinde, öğretmen adaylarının mobil öğrenme tutumları ölçeğine verdikleri yanıtların ortalama beş üzerinden $\bar{x}=3.69$ ile yüksek düzeyde olduğu ve "katıllyorum" şeklinde belirttikleri görülmektedir. İnternet Tabanlı Okuma Motivasyonu ve Katılımları ölçeğine verdikleri yanıtların ortalama 10 üzerinden $\overline{\mathrm{X}}=5.67$ ile orta düzeyde olduğu görülmektedir. Bununla beraber İnternet Tabanlı Okuma Motivasyonu ve Katılımları ölçeğinin yeterlik alt boyutuna yüksek düzeyde ( $\overline{\mathrm{X}}=7.4$ ), zorluk alt boyutuna orta düzeyde $\bar{X}=4.93$, adanmışlık alt boyutuna orta düzeyde $(\bar{X}=6.17)$ ve kaçınma alt boyutuna ise orta düzeyde $(\overline{\mathrm{X}}=4.16)$ motivasyona sahip oldukları gözlenmiştir.

Tablo 7. Ölçeğe ait basıklık ve çarpıklık değerleri

\begin{tabular}{lll}
\hline Boyut & Çarpıklık & Basıklık \\
\hline Mobil Öğrenme Tutumları & -.561 & .657 \\
İnternet Tabanlı Okuma Motivasyonu ve Katılımları & 1.030 & 1.637 \\
Yeterlik Boyutu & -.362 & -.344 \\
Zorluk Boyutu & .646 & -.112 \\
Adanmışlık Boyutu & .195 & -.275 \\
Kaçınma Boyutu & 1.113 & .440 \\
\hline
\end{tabular}

Tablo 7 incelendiğinde Mobil Öğrenme Tutumları ölçeğinin tamamının (Çarpıklık: -.561, Basıklık: .657), İnternet Tabanlı Okuma Motivasyonu ve Katılımları ölçeğinin tamamının (Çarpıklık: 1.030, Basıklık: 1.637), yeterlik alt boyutunun (Çarpıklık: -.362, Basıklık: -.344), zorluk alt boyutunun (Çarpıklık: .646, Basıklık: -.112), adanmışlık alt boyutunun (Çarpıklık: .195, Basıklık: -.275) ve kaçınma alt boyutunun (Çarpıklık: 1.113, Basıklık: .440) -2 ile +2 arasında değer aldığı ortaya çıkmaktadır. George ve Mallery’e göre (2010) normalliği sağlayan değer aralıkları (+2.0) - (-2.0) arasındadır. Bu çerçevede ölçekler ve alt

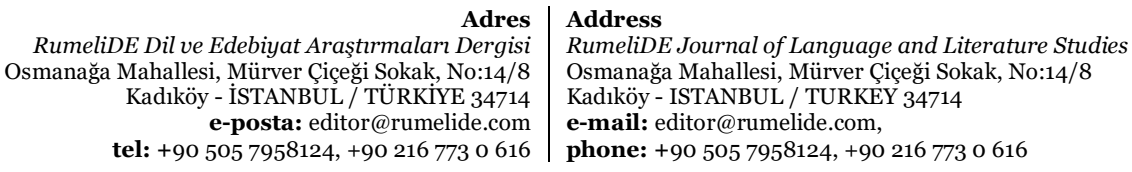


boyutlardan elde edilen verilerin -2 ile +2 arasında değer alması dikkate alındığında bu araştırmada analizler için parametrik (normal dağılım gösteren) testler uygulanacaktır.

Türkçe öğretmeni adaylarının internet tabanlı okuma motivasyonu ve etkileşim algılarının ve ölçeği oluşturan alt boyutlara göre algılarının cinsiyet değişkenine göre farklılaşıp farklılaşmadığını belirlemek amacıyla bağımsız gruplar t testi uygulanmış ve sonuçlar Tablo 8'de gösterilmiştir. Bununla beraber Türkçe öğretmeni adaylarının mobil öğrenme tutumlarının cinsiyet değişkenine göre farklılaşıp farklılaşmadığını belirlemek amacıyla bağımsız gruplar t testi uygulanmış ve sonuçlar Tablo 9'da gösterilmiştir.

Tablo 8. Türkçe öğretmeni adaylarının internet tabanlı okuma motivasyonu ve etkileşim düzeylerinin cinsiyet değişkenine göre analiz sonuçları

\begin{tabular}{llllllll}
\hline Boyut & Cinsiyet & $\mathbf{N}$ & $\overline{\mathbf{x}}$ & $\mathbf{S s}$ & $\mathbf{S d}$ & $\mathbf{t}$ & $\mathbf{p}$ \\
\hline Yeterlik & Kadın & 149 & 7.36 & 1.79 & 195 & -.48 & .63 \\
& Erkek & 48 & 7.51 & 1.88 & & & \\
Zorluk & Kadın & 149 & 4.82 & 2.09 & 195 & -1.28 & .20 \\
& Erkek & 48 & 5.27 & 2.18 & & & \\
Adanmışlık & Kadın & 149 & 6.14 & 1.92 & 195 & -.31 & .75 \\
& Erkek & 48 & 6.25 & 1.97 & & & \\
Kaçınma & Kadın & 149 & 4.12 & 2.24 & 195 & -.48 & .63 \\
& Erkek & 48 & 4.30 & 2.28 & & & \\
Toplam & Kadın & 149 & 5.61 & 1.29 & 195 & -1.02 & .30 \\
& Erkek & 48 & 5.83 & 1.26 & & & \\
\hline
\end{tabular}

Tablo 8'de görüldüğü gibi Türkçe öğretmeni adaylarının internet tabanlı okuma motivasyonu ve etkileşim ölçeğinin bütünü dikkate alındığında cinsiyet değişkeni açısından anlamlı bir fark göstermemektedir $(\mathrm{t}(195)=-1.02, \mathrm{p}>$.05). Bununla beraber ölçeğin alt boyutları incelendiğinde yeterlik $(\mathrm{t}(195)=-.48, \mathrm{p}>.05)$, zorluk $(\mathrm{t}(195)=-1.28, \mathrm{p}>.05)$, adanmışlı $(\mathrm{t}(195)=-.31, \mathrm{p}>.05)$, kaçınma $(\mathrm{t}(195)=-.48, \mathrm{p}>.05)$ alt boyutlarında cinsiyet değişkeni açısından anlamlı bir fark göstermemektedir.

Tablo 9. Türkçe öğretmeni adaylarının mobil öğrenme tutum düzeylerinin cinsiyet değişkenine göre analiz sonuçları

\begin{tabular}{llllllll}
\hline Boyut & Cinsiyet & $\mathbf{N}$ & $\overline{\mathbf{x}}$ & Ss & Sd & t & p \\
\hline Toplam & Kadın & 149 & 3.59 & .73 & 195 & -1.17 & .24 \\
& Erkek & 48 & 3.74 & .90 & & & \\
\hline
\end{tabular}

Tablo 7’de görüldüğü gibi Türkçe öğretmeni adaylarının mobil öğrenme tutumları, ölçeğin bütünü dikkate alındığında cinsiyet değişkeni açısından anlamlı bir fark göstermemektedir (t(195) = -1.17, p > $.05)$.

Sınıf düzeyi değişkeni açısından ölçeğin bütünü ve alt boyutları dikkate alındığında Türkçe öğretmeni adaylarının internet tabanlı okuma motivasyonu ve etkileşimlerine yönelik algı düzeylerinin farklılaşıp farklılaşmadığını belirlemek amacıyla Tek yönlü ANOVA testi uygulanmıştır. Uygulanan testler sonucunda elde edilen sonuçlar Tablo 10' de gösterilmiştir.

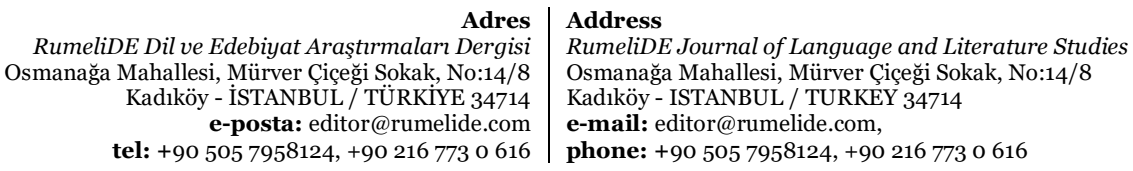


Examining the relationship between prospective Turkish teachers internet based reading motivation and engagement and mobile learning attitude / A. Güzel; Y. M. Elkıran (pp. 324-341)

Tablo 1o. Türkçe öğretmeni adaylarının internet tabanlı okuma motivasyonu ve etkileşimlerinin sınıf düzeyi değişkenine göre tek yönlü anova analiz sonuçları

\begin{tabular}{|c|c|c|c|c|c|c|c|}
\hline & $\begin{array}{l}\text { Varyansin } \\
\text { Kaynağı }\end{array}$ & $\begin{array}{l}\text { Kareler } \\
\text { Toplamı }\end{array}$ & sd & $\begin{array}{l}\text { Kareler } \\
\text { Ortalaması }\end{array}$ & $\mathbf{F}$ & $\mathbf{p}$ & $\begin{array}{l}\text { Anlamlı } \\
\text { Fark }\end{array}$ \\
\hline \multirow[t]{3}{*}{ Yeterlik } & Gruplararası & 22.366 & 3 & 7.455 & 2.312 & .077 & \\
\hline & Gruplariçi & 622.417 & 193 & 3.225 & & & \\
\hline & Toplam & 644.783 & 196 & & & & \\
\hline \multirow[t]{3}{*}{ Zorluk } & Gruplararası & 10.512 & 3 & 3.504 & .776 & .509 & \\
\hline & Gruplariçi & 871.938 & 193 & $4 \cdot 518$ & & & \\
\hline & Toplam & 882.450 & 196 & & & & \\
\hline \multirow[t]{3}{*}{ Adanmışlık } & Gruplararası & 6.421 & 3 & 2.140 & .572 & .634 & \\
\hline & Gruplariçi & 722.378 & 193 & 3.743 & & & \\
\hline & Toplam & 728.799 & 196 & & & & \\
\hline \multirow[t]{3}{*}{ Kaçınma } & Gruplararası & 16.841 & 3 & 5.614 & 1.113 & .345 & \\
\hline & Gruplariçi & 973.075 & 193 & 5.042 & & & \\
\hline & Toplam & 989.915 & 196 & & & & \\
\hline \multirow[t]{3}{*}{ Toplam } & Gruplararası & 6.598 & 3 & 2.199 & 1.326 & .267 & \\
\hline & Gruplariçi & 320.204 & 193 & 1.659 & & & \\
\hline & Toplam & 326.802 & 196 & & & & \\
\hline
\end{tabular}

Tablo 10 dikkate alındığında Türkçe öğretmeni adaylarının internet tabanlı okuma motivasyonu ve etkileşimleri sınıf düzeyi değişkenine göre anlamlı farklılık göstermemektedir [F(3-193)=1.326; p>.05]. Bununla beraber yeterlik $[\mathrm{F}(3-193)=2.312 ; \mathrm{p}>.05]$, zorluk $[\mathrm{F}(3-193)=.776 ; \mathrm{p}>.05]$, adanmışlık $[\mathrm{F}(3-$ $193)=.572 ; \mathrm{p}>.05]$ ve kaçınma $[\mathrm{F}(3-193)=1.113 ; \mathrm{p}>.05]$ alt boyutlarında da sınıf düzeyi değişkenine göre anlamlı bir farklılık göstermemektedir.

Sınıf değişkeni açısından ölçeğin bütünü dikkate alındığında Türkçe öğretmeni adaylarının mobil öğrenme tutumlarının farklılaşıp farklılaşmadığını belirlemek amacıyla Tek yönlü ANOVA testi uygulanmıştır. Uygulanan testler sonucunda elde edilen sonuçlar Tablo 11' de gösterilmiştir.

Tablo 11.Türkçe öğretmeni adaylarının mobil öğrenme tutumlarının sınıf değişkenine göre tek yönlü anova analiz sonuçları

\begin{tabular}{lllllll}
\hline $\begin{array}{l}\text { Varyansın } \\
\text { Kaynağı }\end{array}$ & $\begin{array}{l}\text { Kareler } \\
\text { Toplamı }\end{array}$ & sd & $\begin{array}{l}\text { Kareler } \\
\text { Ortalaması }\end{array}$ & F & p & Anlamlı Fark \\
\hline Gruplararası & 7.588 & 3 & 2.529 & 4.342 & .071 & - \\
Gruplariçi & 112.439 & 193 & .583 & & & \\
Toplam & 120.027 & 196 & & & & \\
\hline
\end{tabular}

Tablo 11 dikkate alındığında Türkçe öğretmeni adaylarının mobil öğrenme tutumlarının sınıf değişkenine göre anlamlı bir fark göstermemektedir [F(3-193) =4.342, p>.05].

Akademik başarı düzeyi değişkeni açısından ölçeğin bütünü ve alt boyutları dikkate alındığında Türkçe öğretmeni adaylarının internet tabanlı okuma motivasyonu ve etkileşimlerine yönelik algı düzeylerinin farklılaşıp farklılaşmadığını belirlemek amacıyla Tek yönlü ANOVA testi uygulanmıştır. Uygulanan testler sonucunda elde edilen sonuçlar Tablo 12' de gösterilmiştir.

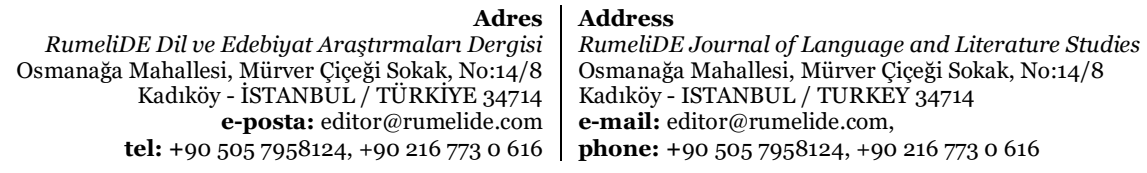


Tablo 12. Türkçe öğretmeni adaylarının internet tabanlı okuma motivasyonu ve etkileşimlerinin akademik başarı düzeyi değişkenine göre tek yönlü anova analiz sonuçları

\begin{tabular}{|c|c|c|c|c|c|c|c|}
\hline & $\begin{array}{l}\text { Varyansın } \\
\text { Kaynağı }\end{array}$ & $\begin{array}{l}\text { Kareler } \\
\text { Toplamı }\end{array}$ & sd & $\begin{array}{l}\text { Kareler } \\
\text { Ortalaması }\end{array}$ & $\mathbf{F}$ & $\mathbf{p}$ & $\begin{array}{l}\text { Anlamlı } \\
\text { Fark }\end{array}$ \\
\hline \multirow[t]{3}{*}{ Yeterlik } & Gruplararası & 22.132 & 2 & 11.066 & 3.448 & .134 & \\
\hline & Gruplariçi & 622.651 & 194 & 3.210 & & & \\
\hline & Toplam & 644.783 & 196 & & & & \\
\hline \multirow[t]{3}{*}{ Zorluk } & Gruplararası & $7 \cdot 931$ & 2 & 3.966 & .880 & .417 & \\
\hline & Gruplariçi & 874.519 & 194 & 4.508 & & & \\
\hline & Toplam & 882.450 & 196 & & & & \\
\hline \multirow[t]{3}{*}{ Adanmışlık } & Gruplararası & 16.935 & 2 & 8.467 & 2.308 & .102 & \\
\hline & Gruplariçi & 711.864 & 194 & 3.669 & & & \\
\hline & Toplam & 728.799 & 196 & & & & \\
\hline \multirow[t]{3}{*}{ Kaçınma } & Gruplararası & 92.452 & 2 & 46.226 & 9.992 & $.000^{*}$ & $\mathrm{~A}-\mathrm{C}$ \\
\hline & Gruplariçi & 897.463 & 194 & 4.626 & & & $\mathrm{~B}-\mathrm{C}$ \\
\hline & Toplam & 989.915 & 196 & & & & \\
\hline \multirow[t]{3}{*}{ Toplam } & Gruplararası & 2.096 & 2 & 1.048 & .626 & .536 & \\
\hline & Gruplariçi & 324.706 & 194 & 1.674 & & & \\
\hline & Toplam & 326.802 & 196 & & & & \\
\hline
\end{tabular}

$\mathrm{p}^{*}<.05, \mathrm{~A}: 0-2.5, \mathrm{~B}: 2.51-3.00, \mathrm{C}: 3.01-4.00$

Tablo 12 dikkate alındığında Türkçe öğretmeni adaylarının internet tabanlı okuma motivasyonu ve etkileşimleri akademik başarı düzeyi değişkenine göre ölçeğin bütünü dikkate alındığında anlamlı fark göstermemektedir $[\mathrm{F}(2-194)=.626 ; \mathrm{p}>.05]$. Bunla beraber yeterlik $[\mathrm{F}(2-194)=3.448 ; \mathrm{p}>.05]$, zorluk $[\mathrm{F}(2-194)=.880 ; \mathrm{p}>.05]$, adanmışlık $[\mathrm{F}(2-194)=2.308 ; \mathrm{p}>.05]$ alt boyutlarında akademik başarı düzeyi değişkeni açısından anlamlı bir fark göstermemektedir. Ancak kaçınma alt boyutunda ise akademik başarı düzeyi değişkeni değişkenine göre anlamlı fark göstermektedir $[\mathrm{F}(2-194)=9.992 ; \mathrm{p}<.05] . \mathrm{Bu}$ farkın hangi gruplar arasında kaynaklandığını ortaya çıkarmak amacıyla Tukey testi yapılmıştır. Tukey testine göre not ortalaması 0-2.5 puan olanlar $(\overline{\mathrm{X}}=5.12)$ ile not ortalaması 2.51-3.00 puan olan Türkçe ögretmeni adaylarının ( $\bar{x}=4.96)$ internet tabanlı okuma motivasyonu ve etkileşimlerinin not ortalaması 3.01-4.0o puan olan Türkçe öğretmeni adaylarına göre $(\overline{\mathrm{X}}=3.59)$, not ortalaması 0-2.5 puan ve 2.51-3.00 puan olan Türkçe öğretmeni adaylarının lehine anlamlı bir farklılık göstermektedir.

Akademik başarı düzeyi açısından ölçeğin bütünü dikkate alındığında Türkçe öğretmeni adaylarının mobil öğrenme tutumlarının farklılaşıp farklılaşmadığını belirlemek amacıyla Tek yönlü ANOVA testi uygulanmıştır. Uygulanan testler sonucunda elde edilen sonuçlar Tablo 13' de gösterilmiştir.

Tablo 13. Türkçe öğretmeni adaylarının mobil öğrenme tutumlarının akademik başarı değişkenine göre tek yönlü anova analiz sonuçları

\begin{tabular}{|c|c|c|c|c|c|c|c|}
\hline $\begin{array}{l}\text { Varyansın } \\
\text { Kaynă̆ı }\end{array}$ & $\begin{array}{l}\text { Kareler } \\
\text { Toplamı }\end{array}$ & sd & \multicolumn{2}{|c|}{$\begin{array}{l}\text { Kareler } \\
\text { Ortalaması }\end{array}$} & $\mathbf{F}$ & $\mathbf{p}$ & Anlamlı Fark \\
\hline Gruplararası & .243 & 2 & \multicolumn{2}{|l|}{.122} & .197 & .821 & - \\
\hline Gruplariçi & 119.784 & 194 & \multirow{2}{*}{\multicolumn{2}{|c|}{.617}} & & & \\
\hline Toplam & 120.027 & 196 & & & & & \\
\hline & \multicolumn{3}{|c|}{$\begin{array}{r}\text { RumeliDE Dil ve Edebiyat Araştırmaları Dergisi } \\
\text { Osmanağa Mahallesi, Mürver Çiçeği Sokak, No:14/8 } \\
\text { Kadıköy - İSTANBUL / TÜRKIYE } 34714 \\
\text { e-posta: editor@rumelide.com } \\
\text { tel: +90 505 7958124, +90 } 216773 \text { o } 616\end{array}$} & \multicolumn{4}{|c|}{$\begin{array}{l}\text { RumeliDE Journal of Language and Literature Studies } \\
\text { Osmanağa Mahallesi, Mürver Çiçeği Sokak, No:14/8 } \\
\text { Kadıköy - ISTANBUL / TURKEY } 34714 \\
\text { e-mail: editor@rumelide.com, } \\
\text { phone: +90 505 7958124, +90 } 216773 \text { o } 616\end{array}$} \\
\hline
\end{tabular}


Tablo 11 dikkate alındı ̆̆ında Türkçe öğretmeni adaylarının mobil öğrenme tutumlarının akademik başarı düzeyi değişkenine göre anlamlı bir fark göstermemektedir $\left[\mathrm{F}_{(2-194)}=.197, \mathrm{p}>.05\right]$.

Yıllık ortalama kitap okuma değişkeni açısından ölçeğin bütünü ve alt boyutları dikkate alındığında Türkçe öğretmeni adaylarının internet tabanlı okuma motivasyonu ve etkileşimlerine yönelik algı düzeylerinin farklılaşıp farklılaşmadığını belirlemek amacıyla Tek yönlü ANOVA testi uygulanmıştır. Uygulanan testler sonucunda elde edilen sonuçlar Tablo 14' de gösterilmiştir.

Tablo 14. Türkçe öğretmeni adaylarının internet tabanlı okuma motivasyonu ve etkileşimlerinin yıllık ortalama kitap okuma değişkenine göre tek yönlü anova analiz sonuçları

\begin{tabular}{|c|c|c|c|c|c|c|c|}
\hline & $\begin{array}{l}\text { Varyansın } \\
\text { Kaynağı }\end{array}$ & $\begin{array}{l}\text { Kareler } \\
\text { Toplamı }\end{array}$ & sd & $\begin{array}{l}\text { Kareler } \\
\text { Ortalaması }\end{array}$ & $\mathbf{F}$ & $\mathbf{p}$ & $\begin{array}{l}\text { Anlamlı } \\
\text { Fark }\end{array}$ \\
\hline \multirow[t]{3}{*}{ Yeterlik } & Gruplararası & 30.295 & 3 & 10.098 & 3.172 & $.025^{*}$ & B-C \\
\hline & Gruplariçi & 614.488 & 193 & 3.184 & & & \\
\hline & Toplam & 644.783 & 196 & & & & \\
\hline \multirow[t]{3}{*}{ Zorluk } & Gruplararası & 19.040 & 3 & 6.347 & 1.419 & .239 & \\
\hline & Gruplariçi & 863.410 & 193 & 4.474 & & & \\
\hline & Toplam & 882.450 & 196 & & & & \\
\hline \multirow[t]{3}{*}{ Adanmışlık } & Gruplararası & 8.786 & 3 & 2.929 & .785 & .504 & \\
\hline & Gruplariçi & 720.013 & 193 & 3.731 & & & \\
\hline & Toplam & 728.799 & 196 & & & & \\
\hline \multirow[t]{3}{*}{ Kaçınma } & Gruplararası & 15.150 & 3 & 5.050 & 1.000 & .394 & \\
\hline & Gruplariçi & 974.765 & 193 & 5.051 & & & \\
\hline & Toplam & 989.915 & 196 & & & & \\
\hline \multirow[t]{3}{*}{ Toplam } & Gruplararası & 8.900 & 3 & 2.967 & 1.801 & .148 & \\
\hline & Gruplariçi & 317.902 & 193 & 1.647 & & & \\
\hline & Toplam & 326.802 & 196 & & & & \\
\hline
\end{tabular}

$\mathrm{p}^{*}<.05, \mathrm{~A}:$ 0-5 kitap, B:6-10 kitap, C:11-15 kitap, D:16 ve üzeri kitap

Tablo 14 dikkate alındığında Türkçe öğretmeni adaylarının internet tabanlı okuma motivasyonu ve etkileşimleri yıllık ortalama kitap okuma değişkenine göre anlamlı fark göstermemektedir [F(3$193)=1.801 ; \mathrm{p}>.05]$. Bununla beraber zorluk $[\mathrm{F}(3-193)=1.419 ; \mathrm{p}>.05]$, adanmışlık $[\mathrm{F}(3-193)=.785 ;$ $\mathrm{p}>.05]$ ve kaçınma [F(3-193)=1.000; p >.05] alt boyutlarında da ylllk ortalama kitap okuma değişkenine göre anlamlı bir farklılık göstermemektedir. Ancak yeterlik alt boyutunda ise akademik başarı düzeyi değişkeni değişkenine göre anlamlı fark göstermektedir $[\mathrm{F}(3-193)=3.172 ; \mathrm{p}<.05] . \mathrm{Bu}$ farkın hangi gruplar arasında kaynaklandığını ortaya çıkarmak amacıyla Tukey testi yapılmıştır. Tukey testine göre ylllk ortalama 6-10 kitap okuyanlara göre $(\bar{x}=6.88)$, ylllk ortalama 11-15 kitap okuyan Türkçe öğretmeni adaylarının ( $\overline{\mathrm{x}}=7.83)$ internet tabanlı okuma motivasyonu ve etkileşimlerinin ylllık ortalama 11-15 kitap okuyan Türkçe öğretmeni adaylarının lehine anlamlı bir farklılık göstermektedir.

Yıllık ortalama kitap okuma değişkeni açısından ölçeğin bütünü dikkate alındığında Türkçe öğretmeni adaylarının mobil öğrenme tutumlarının farklılaşıp farklılaşmadığını belirlemek amacıyla Tek yönlü ANOVA testi uygulanmıştır. Uygulanan testler sonucunda elde edilen sonuçlar Tablo $15^{\prime}$ de gösterilmiştir.

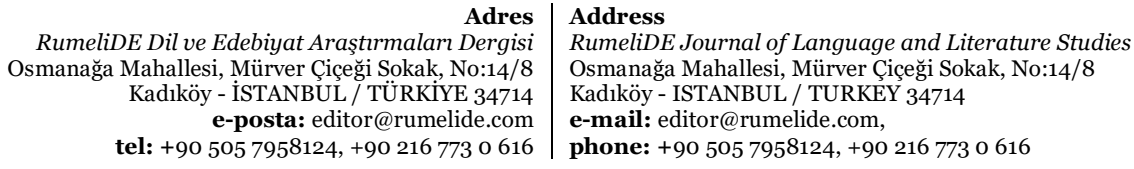


Türkçe öğretmeni adaylarının internet tabanlı okuma motivasyonu ve etkileşim ile mobil öğrenme tutumları arasındaki ilişkinin incelenmesi / A. Güzel; Y. M. Elkıran (324-341. s.)

Tablo 15.Türkçe öğretmeni adaylarının mobil öğrenme tutumlarının yıllık ortalama kitap okuma sayıları değişkenine göre tek yönlü anova analiz sonuçları

\begin{tabular}{lllllll}
\hline $\begin{array}{l}\text { Varyansın } \\
\text { Kaynağı }\end{array}$ & $\begin{array}{l}\text { Kareler } \\
\text { Toplamı }\end{array}$ & sd & $\begin{array}{l}\text { Kareler } \\
\text { Ortalaması }\end{array}$ & F & p & Anlamlı Fark \\
\hline Gruplararası & 2.864 & 3 & .955 & 1.573 & .197 & - \\
Gruplariçi & 117.163 & 193 & .607 & & & \\
Toplam & 120.027 & 196 & & & & \\
\hline
\end{tabular}

Tablo 11 dikkate alındığında Türkçe öğretmeni adaylarının mobil öğrenme tutumları sınıf değişkenine göre anlamlı bir fark göstermemektedir [ $\mathrm{F}_{(3-193)}=1.573$, $\left.\mathrm{p}>.05\right]$.

Bir günde ortalama internette geçirilen süre değişkeni açısından ölçeğin bütünü ve alt boyutları dikkate alındığında Türkçe öğretmeni adaylarının internet tabanlı okuma motivasyonu ve etkileşimlerine yönelik algı düzeylerinin farklılaşıp farklılaşmadı̆̆ını belirlemek amacıyla Tek yönlü ANOVA testi uygulanmıştır. Uygulanan testler sonucunda elde edilen sonuçlar Tablo 16' de gösterilmiştir.

Tablo 16. Türkçe öğretmeni adaylarının internet tabanlı okuma motivasyonu ve etkileşimlerinin bir günde ortalama internette geçirilen süre değişkenine göre tek yönlü anova analiz sonuçları

\begin{tabular}{|c|c|c|c|c|c|c|c|}
\hline & $\begin{array}{l}\text { Varyansın } \\
\text { Kaynağı }\end{array}$ & $\begin{array}{l}\text { Kareler } \\
\text { Toplamı }\end{array}$ & sd & $\begin{array}{l}\text { Kareler } \\
\text { Ortalaması }\end{array}$ & $\mathbf{F}$ & $\mathbf{p}$ & $\begin{array}{l}\text { Anlamlı } \\
\text { Fark }\end{array}$ \\
\hline \multirow[t]{3}{*}{ Yeterlik } & Gruplararası & 12.517 & 3 & 4.172 & 1.274 & .285 & \\
\hline & Gruplariçi & 632.266 & 193 & 3.276 & & & \\
\hline & Toplam & 644.783 & 196 & & & & \\
\hline \multirow[t]{3}{*}{ Zorluk } & Gruplararası & 1.380 & 3 & .460 & .101 & .960 & \\
\hline & Gruplariçi & 881.071 & 193 & 4.565 & & & \\
\hline & Toplam & 882.450 & 196 & & & & \\
\hline \multirow[t]{3}{*}{ Adanmışlık } & Gruplararası & 22.106 & 3 & $7 \cdot 369$ & 2.012 & .114 & \\
\hline & Gruplariçi & 706.692 & 193 & 3.662 & & & \\
\hline & Toplam & 728.799 & 196 & & & & \\
\hline \multirow[t]{3}{*}{ Kaçınma } & Gruplararası & 8.730 & 3 & 2.910 & .572 & .634 & \\
\hline & Gruplariçi & 981.186 & 193 & 5.084 & & & \\
\hline & Toplam & 989.915 & 196 & & & & \\
\hline \multirow[t]{3}{*}{ Toplam } & Gruplararası & 3.254 & 3 & 1.085 & .647 & .586 & \\
\hline & Gruplariçi & $323 \cdot 548$ & 193 & 1.676 & & & \\
\hline & Toplam & 326.802 & 196 & & & & \\
\hline
\end{tabular}

Tablo 16 dikkate alındığında Türkçe öğretmeni adaylarının internet tabanlı okuma motivasyonu ve etkileşimlerine yönelik algı düzeyleri bir günde ortalama internette geçirilen süre değişkenine göre ölçeğin bütünü dikkate alındığında anlamlı fark göstermemektedir [F(3-193)=.647; p>.05]. Bununla beraber yeterlik $[\mathrm{F}(3-193)=1.274 ; \mathrm{p}>.05]$, zorluk $[\mathrm{F}(3-193)=.101 ; \mathrm{p}>.05]$, adanmışlik $[\mathrm{F}(3-193)=2.012$; $\mathrm{p}>.05]$ ve kaçınma $[\mathrm{F}(3-193)=.572 ; \mathrm{p}>.05]$ alt boyutlarında da akademik başarı düzeyi değişkeni açısından anlamlı bir fark göstermemektedir.

Bir günde ortalama internette geçirilen süre değişkeni açısından ölçeğin bütünü dikkate alındığında Türkçe öğretmeni adaylarının mobil öğrenme tutumlarının farklılaşıp farklılaşmadığını belirlemek

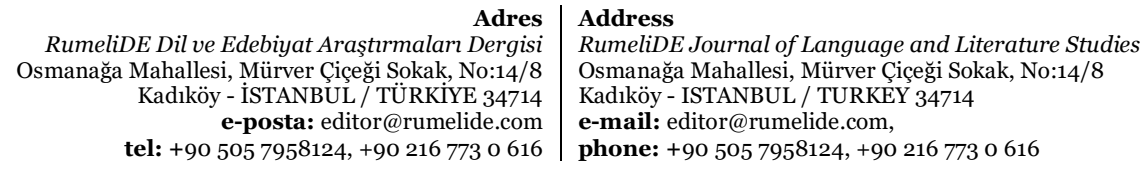


amacıyla Tek yönlü ANOVA testi uygulanmıştır. Uygulanan testler sonucunda elde edilen sonuçlar Tablo 17' de gösterilmiştir.

Tablo 17.Türkçe öğretmeni adaylarının mobil öğrenme tutumlarının bir günde ortalama internette geçirilen süre değişkenine göre tek yönlü anova analiz sonuçları

\begin{tabular}{lllllll}
\hline $\begin{array}{l}\text { Varyansın } \\
\text { Kaynağı }\end{array}$ & $\begin{array}{l}\text { Kareler } \\
\text { Toplamı }\end{array}$ & sd & $\begin{array}{l}\text { Kareler } \\
\text { Ortalaması }\end{array}$ & F & p & Anlamlı Fark \\
\hline Gruplararası & .477 & 3 & .159 & .256 & .857 & - \\
Gruplariçi & 119.550 & 193 & .619 & & & \\
Toplam & 120.027 & 196 & & & & \\
\hline
\end{tabular}

Tablo 17 dikkate alındığında Türkçe öğretmeni adaylarının mobil öğrenme tutumları bir günde ortalama internette geçirilen süre değişkenine göre anlamlı bir fark göstermemektedir $\left[\mathrm{F}_{(3-193)}=.256, \mathrm{p}>.05\right]$.

Tablo 18. Türkçe öğretmeni adaylarının internet tabanlı okuma motivasyonu ve etkileşimleri ile mobil öğrenme tutumlarının arasındaki ilişkiye yönelik pearson korelasyon analizi

\begin{tabular}{llll}
\hline & & Yazma & Okuma \\
\hline Yazma & Pearson Correlation & 1 & $.223^{* *}$ \\
& Sig. (2-tailed) & & $.002^{*}$ \\
Okuma & $\mathrm{N}$ & 197 & 197 \\
& Pearson Correlation & $.223^{* *}$ & 1 \\
& Sig. (2-tailed) & $.002^{*}$ & \\
& $\mathrm{~N}$ & 197 & 197 \\
\hline
\end{tabular}

${ }^{* *}$ Correlation is significant at the 0.01 level (2-tailed)

${ }^{*} \mathrm{p}<.01$ düzeyinde anlamlı fark vardır.

Tablo 18 incelendiğinde Türkçe eğitimi öğretmen adaylarının internet tabanlı okuma motivasyonu ve etkileşimleri ile mobil öğrenme tutumları arasında zayıf düzeyde, pozitif ve anlamlı bir ilişki olduğu görülmektedir [r=0.223, $\mathrm{p}<.01]$. Buna göre öğretmen adaylarının yazması arttıkça okumasının da arttığı söylenebilir. Determinasyon katsayısı [ $\left.\mathrm{r}^{2}=.05\right]$ dikkate alındığında internet tabanlı okuma motivasyonu ve etkileşimleri ölçeğindeki toplam varyansın \%o5’inin mobil öğrenme ölçeğinden kaynaklandığı söylenebilir.

\section{Sonuç, tartışma ve öneriler}

$\mathrm{Bu}$ araştırmada Türkçe öğretmeni adaylarının dijital yazma tutumları ile dijital okuma eğilimleri arasındaki ilişki belirlenmeye çalışılmıştır. Araştırmaya Türkiye'nin batısındaki bir üniversitede öğrenim gören 197 öğretmen adayı katılmıştır. Katılımcıların 149'unu kadın, 48'ini erkek öğretmen adayları oluşturmaktadır. Katılımcıların 28'ini birinci sınıf , 30'unu ikinci sınıf , 79'unu üçüncü sınıf, 6o'ını ise dördüncü sınıf öğrencileri oluşturmaktadır. Katılımcıların 13'ünün 0-2.5 puan arası, 68'inin 2.51-3.00 puan arası ve 116'sının 3.01-4.0 puan arası akademik başarı puanına sahip olduğu anlaşılmıştır. Katılımcıların bir yılda ortalama 39'unun o-5 kitap, 63'ünün 6-10 kitap, 41'inin 11-15 kitap, 54 'ünün ise 16'dan fazla sayıda kitap okuduğu anlaşılmıştır. Katılımcıların bir günde süre olarak 10'unun o-1 saat, 36'sinın 2-3 saat, 80'inin 4-6 saat, 71'inin ise yediden fazla saat ortalama internette zaman geçirdikleri anlaşılmıştır.

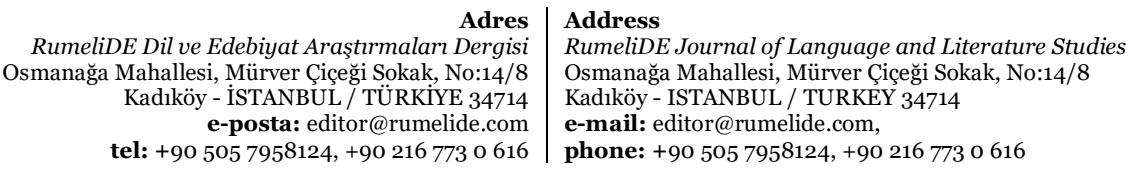


Çalışmanın ana konusunu, Türkçe öğretmeni adaylarının internet tabanlı okuma motivasyonu ve etkileşimleri ile mobil öğrenme tutumları arasındaki ilişki oluşturmaktadır. Teknolojideki gelişmeler, insanların basılı versiyondan dijitalleştirilmiş versiyona okumaya olan ilgilerini değiştiriyor (Tanjung, Ridwan ve Gultom, 2017). En çok alıntı yapılan 100 mobil öğrenme çalışmalarını inceleyen Lai'ye (2020) göre araştırmacılar mobil öğrenmenin etkilerini geleneksel öğretimle karşılaştırmaktansa daha etkili mobil öğrenme yaklaşımları bulmak amacıyla mobil öğrenme metotlarını karşılaştırmaya odaklanmıştır. Literatür incelendiğinde, bu bağlamda gerçekleştirilmiş bir araştırmaya rastlanılmamıştır. Araştırma bulgularına göre Türkçe eğitimi öğretmen adaylarının internet tabanlı okuma motivasyonu ve etkileşimleri ile mobil öğrenme tutumları arasında zayıf düzeyde, pozitif ve anlamlı bir ilişki olduğu sonucuna ulaşılmıştır.

Türkçe eğitimi öğretmen adaylarının internet tabanlı okuma motivasyonu ve etkileşimlerinin orta düzeyde olduğu sonucuna ulaşılmıştır. Literatürde internet tabanlı okuma motivasyonuna yönelik olarak Türkçe öğretmen adayları ile ilgili doğrudan bir araştırmaya rastlanmamıştır. Ancak dolaylı olarak Ülper ve Çeliktürk'ün (2013) çalışmalarında internet üzerinden gazete ve haber okuma güdülerinin yüksek olduğu sonucuna ulaşılmıştır. Okuma motivasyonu konusundaysa Türkçe öğretmen adayları ile çalışılmış olarak bazı araştırmalara rastlanmıştır. Karahan'ın (2015) yaptığı çalışmaya göre öğretmen adaylarının okuma motivasyonlarının iyi düzeyde olduğu sonucuna ulaşılmıştır. Geçgel, Kana, Öztürk ve Akkaş'ın (2020) çalışmalarında Türkçe öğretmeni adaylarının okuma motivasyonlarının yüksek düzeyde olduğu sonucuna ulaşılmıştır.

İnternet tabanlı okuma motivasyonu ve etkileşim ölçeğinin bütünü ve alt boyutları göz önüne alındığında cinsiyet, sınıf düzeyi ve bir günde ortalama internette geçirilen süre değişkenlerine göre anlamlı farklılığa ulaşılamamıştır. Karahan'ın (2015) yaptığı araştırmaya göre öğretmen adaylarının okuma motivasyonlarının cinsiyet değişkenine göre ölçeğin alt boyutlarında kadın öğretmen adaylarının lehine anlamlı bir farklılık sonucuna ulaşılmıştır. Şahin’in (2019) araştırmasında benlik alt boyutunda kadınların lehine bir farklılığa ulaşılmış ve diğer alt boyutlar için cinsiyet değişkenine göre anlamlı bir farklılığa ulaşılmamıştır. Ayrıca sınıf değişkenine göre ise tanınma alt boyutunda 2. sınıfların lehine bir farka ulaşılmışken diğer alt boyutlarda anlamlı bir farklılığa ulaşılamamıştır. Geçgel, Kana, Öztürk ve Akkaş'ın (2020) araştırmalarında Türkçe öğretmeni adaylarının okuma motivasyonlarının cinsiyet değişkenine göre ölçeğin yeterlilik ve tanıma alt boyutlarında anlamlı farklılığa ulaşılamamışken benlik ve diğer alt boyutlarında kadın adayların lehine anlamlı bir farklılık sonuçlarına ulaşılmıştır. Ayrıca Geçgel, Kana, Öztürk ve Akkaş’ın (2020) çalışmalarında sınıf düzeyi değişkeni açısından benlik alt boyutunda üçüncü sınıflar ile dördüncü sınıflar arasında üçüncü sınıfların lehine bir fark bulunmuş ancak diğer tüm boyutlar için anlamlı bir farklılığa ulaşılamamıştır. Bununla beraber Geçgel, Kana, Öztürk ve Akkaş’ın (2020) çalışmalarında Türkçe öğretmen adaylarının internette geçirdikleri süre ile ilgili internette okuma için 2-3 saat geçirenlerin 4-6 saat geçirenlere oranla 2-3 saat geçirenlerin lehine anlamlı bir farklılığa ulaşılmıştır.

İnternet tabanlı okuma motivasyonu ve etkileşimlerinin ölçeğin bütünü, yeterlik, zorluk ve adanmışlık alt boyutlarında akademik başarı düzeyi değişkenine göre anlamlı farklılığa ulaşılamamışken kaçınma alt boyutunda ortalaması 3.01-4.00 puanın altındaki katılımcıların lehine anlamlı farklılık görülmüştür. Ayrıca internet tabanlı okuma motivasyonu ve etkileşimlerinin ölçeğin bütünü, zorluk, adanmışlık ve kaçınma alt boyutlarında yıllık ortalama kitap okuma sayısı değişkenine göre anlamlı farklılığa ulaşılamamışken yeterlik alt boyutunda anlamlı farklılık görülmüştür. Şahin’in (2019) araştırmasına göre yıl içerisinde okunan kitap sayısı arttıkça öğretmen adaylarının okuma motivasyonları artmaktadır. Geçgel, Kana, Öztürk ve Akkaş’ın (2020) çalışmalarında Türkçe öğretmen adaylarının akademik başarı

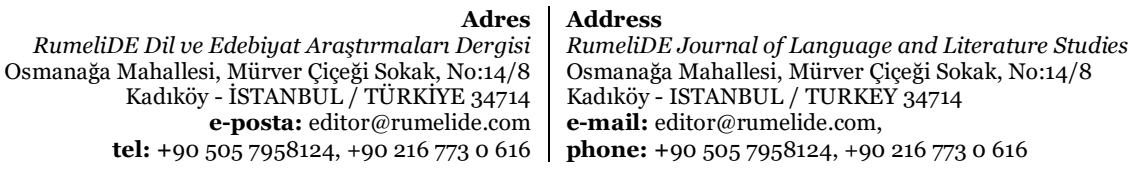


Examining the relationship between prospective Turkish teachers internet based reading motivation and engagement and mobile learning attitude / A. Güzel; Y. M. Elkıran (pp. 324-341)

düzeyleri, 3.00-4.00 puan arasında olanların 0-2.50 arsında olanlara göre 3.00-4.00 puan arasında olanların lehine anlamlı bir farklılığa ulaşılmıştır. Ayrıca Geçgel, Kana, Öztürk ve Akkaş’ın (2020) çalışmalarında Türkçe öğretmen adaylarının yıllık 16 ve üzeri, 11-15 arası ve 6-10 arası yıllık kitap okuyanların 0-5 arası yıllık kitap okuyanlara göre 0-5 arası yıllık kitap okuyanların dışında kalan öğretmen adaylarının lehine anlamlı bir farklılığa ulaşılmıştır.

İnternet tabanlı ortamlar öğrenci merkezlidir ve öğrenenlerin öğrenme sürecine aktif olarak katılmalarını sağlar (Kanellopoulou ve Giannakoulopoulos, 2021). Klimova (2019) mobil öğrenmenin öğrenenlerin ihtiyaçlarına göre tasarlanması gerektiğini böylelikle kalıcı öğrenmeye daha fazla katkı sağlanacağını belirtmiştir. Mobil öğrenmenin örgün öğretime uygun bir tamamlayıcı yöntem olarak hizmet edebileceği düşünülmektedir. Türkçe eğitimi öğretmen adaylarının mobil öğrenme tutumlarının yüksek düzeyde olduğu sonucuna ulaşılmıştır. Benzer şekilde Turgut ve Akdemir'in (2019) yaptıkları araştırmada da öğretmen adaylarının mobil öğrenmeye ilişkin tutumlarının genel olarak olumlu olduğu sonucuna ulaşılmıştır. Mobil öğrenme tutumları içinde ölçeğin bütünü dikkate alındığında cinsiyet, sınıf düzeyi, akademik başarı, yıllık ortalama kitap okuma ve bir günde ortalama internette geçirilen süre değişkenlerine göre anlamlı farklılık görülmemiştir. Turgut ve Akdemir’in (2019) yaptıkları araştırmada da öğretmen adaylarının mobil öğrenmeye ilişkin tutumlarının cinsiyet değişkenine göre anlamlı farklılık göstermezken haftalık internet kullanım sürelerine göre ise interneti daha fazla kullananların lehine anlamlı bir farklılı̆̆a ulaşılmıştır.

21. Yüzyl, toplumların ve bireylerin dijital dünyada var olmasını gerektirmiştir. İş hayatının ve sosyalleşmelerin dijital ve sanal ortamlara taşındığı yeni normaller meydana gelmiştir. Bireyler için bu ortamlarda var olmak ve medyayı takip edip işlerini görebilmek için teknik ve bilişsel bazı yeteneklerin geliştirilmesi mecburiyeti söz konusu olmuştur. Bu durum hem toplumların yaşam koşullarını hem de kültürlerini farklılaşmaya götürmüştür. 21. yüzyll becerileri olarak adlandırılan temel okuryazarlıklar, yetkinlikler ve çevre ile iletişim ile yaşam boyu öğrenme kavramları hayatımızda vazgeçilmez kılınmıştır (Elkıran, 2021, Ustabulut, 2021 ). Bilgi bu dijital ortamlarda sürekli olarak artmakta, gelişmekte ve yayılmaktadır. Gazete ve dergi gibi medya araçları, internetten yayın yapmaya başlamış gün içinde güncel bilgileri internet kullanıcılarına sunmak için mobil teknolojilerine uygun uygulamalar üretmişlerdir. Mobil öğrenme eğitimcilerin kendilerini geliştirmelerine önemli firsatlar sağlar (Qureshi, Khan, Gillani ve Raza, 2020). Türkçe öğretmenleri ve öğretmen adaylarına da bu dijital dünyanın farkına varmaları, kendilerini ve öğrencilerini bu yeni ortamlara karşı farkındalık kazandıracak eğitimler vermelilerdir.

Özellikle dijital araçların ekonomik olarak pahalı olmasından dolayı cihazın bozulma kaygısı öğrenmeleri olumsuz etkileyebilmektedir. Bu gibi kaygıların giderilmesi için hem mobil araçların eğitiminin hem de dijital araçların kullanımlarının eğitimlerinin verilmesi gerekmektedir. Ayrıca üniversitelerde dijital dünyanın olumlu ve olumsuz yönleri için rehberlik sistemlerine de ihtiyaç olduğu anlaşılmaktadır.

İnternet tabanlı forum ve sosyal medya sitelerinin çok yoğun kullanıldığı ve yine bu okuma kaynakların üye, konu ve içerik yönünden zengin okuma materyallerine sahip olduğu görülmektedir. Bu medyaların özellikle anlama ve anlatma dil becerileri yönünden ayrı ayrı incelenerek yeni medya ortamlarına yönelik araştırmaların arttırılarak yoğunlaştırılması gerekmektedir. Öğretmen adayları ve toplumun ilgisini çekebilecek edebi tür ve yazıların okunmasına yönelik olarak firsat oluşturacak çalışmalara ağırlık verilmelidir.

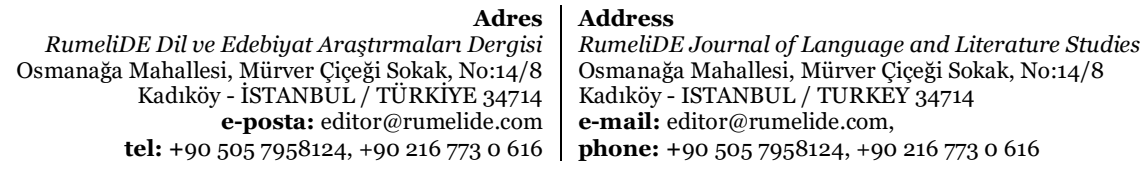


Türkçe konuşma ve yazmanın doğru, güzel ve sade olarak yapılabilmesi için bireylerin temelden başlayarak iyi eğitim almaları gerekmektedir. Bunun yegane temelini de öğretmenlerin ve Türkçe öğretmenlerinin iyi yetişmesi oluşturacaktır. Bu bağlamda görevdeki Türkçe öğretmenlerinin ve Türkçe öğretmeni adayları ile akademisyenlerin doğrudan ücretsiz olarak dijital materyallere erişimlerinde ayrıcalık ve kolaylıklar sağlanabilir. Derslerde kullanmak amacıyla dijital materyalleri sadece yüzyüze değil kayıt altına alınabilen eş zamansız uzaktan eğitimde de telif hakkı ile ilgili ayrıcalıklar sağlanabilir.

\section{Kaynakça}

Abdullah, F. ve Ward, R. (2016). Developing a general extended technology acceptance model for elearning (GETAMEL) by analysing commonly used external factors. Computers in Human Behavior, 56, 238-256.

Akkaya, A., ve Toprak, F. (2020) Görsel okuryazarlık karikatürlerle Türkçe dersi işleme süreci. Elazı̆̆:Asos yayıncılık

Ata, R., ve Alpaslan, M. M. (2019). İnternet tabanlı okuma motivasyonu ve etkileşim ölçeği Türkçe'ye uyarlama çalışması ve öğretmen adayları ile bir inceleme. Eğitim Teknolojisi Kuram ve Uygulama, 9(2), 522-538.

Baki, Y. (2019). Türkçe öğretmeni adaylarının üst bilişsel okuma stratejilerinin okuma motivasyonu üzerindeki etkisinde sınıf düzeyinin ve cinsiyetin rolü. Marmara Üniversitesi Atatürk Eğitim Fakültesi Ĕ̆itim Bilimleri Dergisi, 50(50), 15-42.

Braten, I., Brandmo, C., ve Kammerer, Y. (2019). A validation study of the internet-specific epistemic justification inventory with Norwegian preservice teachers. Journal of Educational Computing Research, 57, 877-900.

Bulun, M., Gülnar, B. ve Güran, M. S. (2004). Eğitimde mobil teknolojiler. The Turkish Online Journal of Educational Technology, 3(2), 165-169.

Bulut, B. ve Karasakaloğlu, N. (2018). Digital reading disposition scale: A Study of Validity and Reliability. Universal Journal of Educational Research, 6(4), 613-618.

Büyüköztürk, Ş., Çakmak, E., Akgün, Ö. E., Karadeniz, Ş., ve Demirel, F. (2018). Eğitimde bilimsel araştırma yöntemleri. Ankara: Pegem akademi.

Churchill, N. (2016). Digital storytelling as a means of supporting digital literacy learning in an upperprimaryschool English language classroom. (Unpublished Doctoral dissertation, Edith Cowan University). Retrieved from https://ro.ecu.edu.au/theses/1774

Çam, E., Uysal, M., Kıyıcı, M., ve İşbulan, O. (2019). Mobil öğrenme tutum ölçeğinin Türk kültürüne uyarlanması. Uluslararası Türk Ĕ̆itim Bilimleri Dergisi, 2019(13), 114-125.

Duran, E., ve Özen, N. E. (2018). Türkçe derslerinde dijital okuryazarlık. Türkiye Eğitim Dergisi, 3(2), $31-46$.

Duran, E., ve Özkul, İ. D. (2015). Ekran okuryazarlığının gelişimi ve geleceğine yönelik tahminler. Uşak Üniversitesi Sosyal Bilimler Dergisi, 8(4), 281-297.

Elkıran, Y.M. (2021). Türkçe öğretmeni adaylarının hayat boyu öğrenme ve yetişkin eğitimi eğilimleri. Route Educational ve Social Science Journal, 8(6), 152-160.

Erbaş, C.., ve Demirer, V. (2015). Eğitimde sanal ve artırılmış gerçeklik uygulamaları. B. Akkoyunlu, A. İşman ve H. F. Odabaşı (Ed.), Eğitim teknolojileri okumaları 2015 içinde (s. 131-148). Ankara.

Fagerberg, T., Rekkedal, T. ve Russell, J. (2003). Designing and trying out a learning environment for mobile learners and teachers. Design, Development and Evaluation of Mobile Learning at NKI Distance Education, 2000-2005, 85.

Geçgel, H., Kana, F., Öztürk, N. E., ve Akkaş, İ. (2020). Öğretmen adaylarının okuma motivasyonları ve sosyal medyaya özgü epistemolojik inançları arasındaki ilişkinin incelenmesi. Dil Eğitimi ve Araştırmaları Dergisi, 6(2), 478-507.

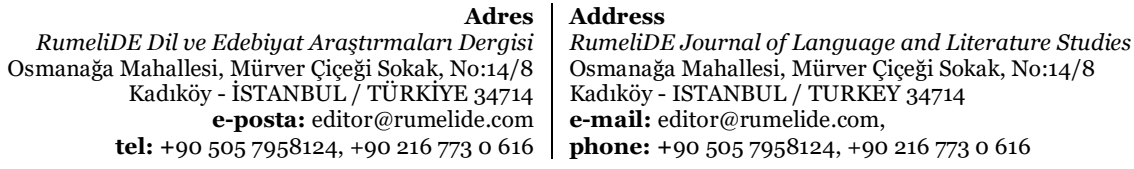


Examining the relationship between prospective Turkish teachers internet based reading motivation and engagement and mobile learning attitude / A. Güzel; Y. M. Elkıran (pp. 324-341)

George, D., ve Mallery, M. (2010). SPSS for Windows step by step: A simple guide and reference. Pearson Education India.

Gilster, P. (1997). Digital literacy. John Wiley ve Sons, Inc..

Göçer, A., ve Tabak, G. (2013). Öğretmen adaylarının 'görsel okuryazarlık' ile ilgili algıları. Adıyaman Üniversitesi Sosyal Bilimler Enstitüsü Dergisi, (11), 517-541.

Guthrie, J.T., Anderson, E., Alao, S., ve Rinehart, J. (1999). Influences of concept-oriented reading instruction on strategy use and conceptual learning from text. Elementary School Journal, 99, 343-366.

Güneş, F. (2016). Kağıttan ekrana okuma alanındaki gelişmeler (from paper to screen developments in the field of reading. Bartin University Journal of Faculty of Education, 5(1), 1-18.

Güneş, F. ve Susar K.F. (2014). E-kitap okumaya yönelik tutum ölçeğinin (EKOT) geliştirilmesi: Geçerlilik ve güvenirlik çalışması. Bartın Üniversitesi Eğitim Fakültesi Dergisi, 3(2), 196 - 212

Kana, F. (2015). Ortaokul öğrencilerinin okuma stillerinin incelenmesi. Journal of International Social Research, 8(40).

Kanellopoulou, C., ve Giannakoulopoulos, A. (2021). Internet-Assisted Language Teaching: The Internet as a Tool for Personalised Language Exploration. Creative Education, 12(03), 625.

Karahan, B. Ü. (2015). Öğretmen adaylarının okumaya yönelik motivasyonlarının çeşitli değişkenler açısından incelenmesi (Kafkas Üniversitesi örneği). Electronic Turkish Studies, 1O(11).

Karasar, N. (2007). Bilimsel araştırma yöntemi . Ankara:Nobel yayın dağıtım.

Klimova, B. (2019). Impact of mobile learning on students' achievement results. Education Sciences, 9(2), 90.

Knezek, G. ve Khaddage, F. (2012). Bridging formal and informal learning: A mobile learning attitude scale for higher education. British journal of social sciences, 1(2), 101-116.

Kukulska-Hulme, A. ve Traxler, J. (2005). Mobile learning: A handbook for educators and trainers. London: Routledge.

Kurudayığlu, M., ve Çetin, Ö. (2015). Temel beceriler ve Türkçe öğretimi. Ana Dili Eğitimi Dergisi, 3(3), 1-19.

Lai, C. L. (2020). Trends of mobile learning: A review of the top 100 highly cited papers. British Journal of Educational Technology, 51(3), 721-742.

Larson, L. C. (2012). It's time to turn the digital page: Preservice teachers explore e-book reading. Journal of Adolescent and Adult Literacy, 56(4), 280-290.

Macit, I., ve Demir, M. K. (2016). Dördüncü sınıf öğrencilerinin ekran okuma becerilerinin değerlendirilmesi. Turkish Studies (Elektronik), 11(3), 1647-1664.

Maden, S. (2012). Ekran okuma türleri ve Türkçe ögretmeni adaylarının ekran okumaya yönelik görüsleri/Screen Reading Types and Opinions of Prospective Teacher of Turkish Language towards Screen Reading. Dil ve Edebiyat Egitimi Dergisi, 1(3), 1.

Özden, M. (2019).Okur olarak Türkçe eğitimi lisans öğrencileri.Route Education and Social Science Journal Volume 6(11), December 2019 ss. 951-959.

Sulak, S.E. (2019). Dijital okuryazarlık ölçeğinin geliştirilmesi: geçerlik ve güvenirlik çalışması. Social Sciences Studies Journal, 5(3), 1329-1342.

Susar K.F. (2017). Ekrandan okumaya yönelik tutum ölçeğinin (EKYÖTÖ) eliştirilmesi: Geçerlilik ve güvenirlik çalışması. International Journal of Languages' Education and Teaching, 5(1), 286301.

Şahin, N. (2019). Türkçe öğretmeni adaylarının okuma motivasyonlarının çeşitli değişkenler açısından incelenmesi. OPUS Uluslararası Toplum Araşttrmaları Dergisi, 13(19), 393-423.

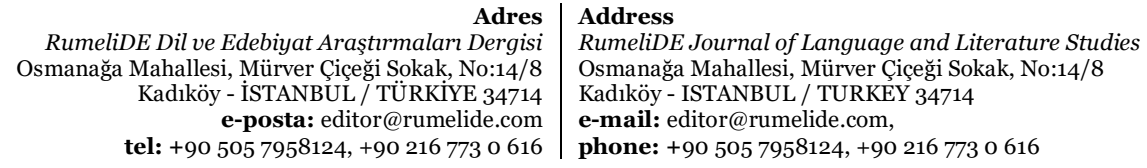


Tanjung, F. Z., Ridwan, R., ve Gultom, U. A. (2017). Reading habits in digital era: A research on the students in Borneo university. LLT Journal: A Journal on Language and Language Teaching, 2O(2), 147-157.

Turgut, K. ve Akdemir, E . (2019). Öğretmen adaylarının mobil öğrenmeye ilişkin tutumları. OPUS Uluslararası Toplum Araştırmaları Dergisi , 13(19) , 500-526.

Qureshi, M. I., Khan, N., Gillani, H. S. M. A., ve Raza, H. (2020). A Systematic Review of Past Decade of Mobile Learning: What we Learned and Where to Go. International Journal of Interactive Mobile Technologies, 14(6).

Ulu, H. (2018). Ekran okuma öz yeterlik ölçeği: Geçerlik ve güvenirlik çalışması. Ana Dili Eğitimi Dergisi, 6(1), 148- 165 .

Ustabulut, M. Y. (2021). Türkçe öğretmeni adaylarının yaşam becerileri ile ilgili görüşlerinin çeşitli değişkenler açısından incelenmesi. Kahramanmaraş Sütçü İmam Üniversitesi Sosyal Bilimler Dergisi, 18 (1) , 205-219.

Ülper, H., ve Çeliktürk, Z. (2013). Öğretmen adaylarının okuma motivasyonlarının değerlendirilmesi: Mehmet Akif Ersoy Üniversitesi örneği. Journal of Social Sciences/Sosyal Bilimler Dergisi, 6(11).

Wigfield, A., ve Guthrie, J. T. (1997). Relations of children's motivation for reading to the amount and breadth of their reading. Journal of Educational Psychology, 89, 420-432.

Yurdakal, İ. H. ve Susar K.F. (2021). Öğretmen adayları için dijital okumaya yönelik tutum ölçeği (dotö): geçerlik güvenirlik çalışması. Dokuz Eylül Üniversitesi Buca Eğitim Fakültesi Dergisi, (51), 137159.

RumeliDE Dil ve Edebiyat Araştırmaları Dergisi Osmanağa Mahallesi, Mürver Çiçeği Sokak, No:14/8 Kadıköy - İSTANBUL / TÜRKIYE 34714 e-posta: editor@rumelide.com tel: +90 $5057958124,+902167730616$
Address

RumeliDE Journal of Language and Literature Studies Osmanağa Mahallesi, Mürver Çiçeği Sokak, No:14/8

Kadıköy - ISTANBUL / TURKEY 34714

e-mail: editor@rumelide.com,

phone: +90 5057958124 , +90 2167730616 